\section{THE POLITICS OF HYBRIDITY AND MESTIZAJE IN U.S. LATINO POPULAR MUSIC}

\author{
Deborah Pacini Hernández \\ Professor of Anthropology \\ Tufts University \\ deborah.pacini@tufts.edu
}

\section{LAS POLÍTICAS DE HIBRIDEZ $Y$ MESTIZAJE EN LA MÚSICA POPULAR DE LOS LATINOS EN LOS ESTADOS UNIDOS}

\begin{abstract}
RESUMEN: Por mucho tiempo, las teorías del mestizaje han sido utilizadas para analizar e interpretar la hibridez de las identidades y culturas latinoamericanas, pero el mestizaje -al igual que sus críticas- no es un concepto adecuado en el caso de los espacios sociales, culturales y políticos que ocupan en los Estados Unidos las comunidades latinas y sus producciones musicales. A través del análisis de las profundas líneas de falla que existen en la intersección de los conceptos latinoamericanos de mestizaje y los conceptos bipolares estadounidenses sobre raza e identidad racial, este ensayo dilucida el impacto concreto y material que estas discrepancias conceptuales tienen en las comunidades latinas estadounidenses y en sus prácticas musicales.
\end{abstract}

PALABRAS CLAVE: Mestizaje; hibridez; latinos en Estados Unidos; música popular.

Any discussion of issues related to Latin/o American popular music must begin with a discussion of terminology, and this essay is no exception. While the Spanish term latino may be used in Latin America as shorthand for Latino Americanos, in the United States the term Latino refers specifically to individuals with some degree of Latin American ancestry who reside in the U.S. Unlike Latin American latinos, U.S. Latinos, especially those born and raised in the United States, do not necessarily speak Spanish and many have never been to Latin America. Also unlike Latin American latinos, U.S. Latinos identify and/or are identified as a domestic minority, although they are often incorrectly imagined as a race (like African Americans) rather than as ethnic communities linked to different Latin American nations and national cultures (e.g. Mexican Americans, Cuban Americans, etc.). In this essay, which focuses primarily on the United States, I use the term Latino to refer to people and culture located within the United States; I use the term Latin/o Americans to refer to Latin Americans and US Latinos collectively?.

\begin{abstract}
Theories of mestizaje have long been used to analyze and interpret the hybridity of Latin American cultures and identities, but mestizaje -as well as its critiques- do not map neatly onto the social, cultural and political landscape in which U.S. Latino communities and their musical productions are embedded. In addressing the deep fault lines at the intersections of Latin American concepts of mestizaje and the United States' bipolar concepts of race and racial identity, this essay sheds light on the very concrete and material impacts these conceptual descrepancies have had on U.S. Latino communities and their musical practices.
\end{abstract}

KEY WORDS: Mestizaje; hybridity; US Latinos; popular music.

Latin Americans and their U.S. Latino counterparts are (whether they admit to it or not) fundamentally hybrid peoples: they are genetically and/or culturally the products of the European invasion and colonization of Amerindian lands that began in 1492, and the African peoples subsequently dragged involuntarily into the process by colonial Europeans. In Latin America, the term mestizo emerged to describe people and culture of mixed European and native ancestry; the related term mestizaje has commonly been used to refer to the process of cultural mixing that accompanied biological mixing. Because these terms are based on the Spanish verb mezclar (to mix), in principle they can refer to people and culture of mixed European and African ancestries as well, but in practice they are generally used to describe Native (indigenous)/European hybridity. The analogous term describing the descendants of a European/African mix -mulatto- is less commonly used and then only to describe people; references to "mulatto culture" are rare. In the Spanish Caribbean, which received hundreds of thousands of enslaved Africans in 
the colonial period, African/European cultural hybridity is more often described with the term "creole", which signals the mixtures produced in the Americas in the wake of European conquest, colonization, and slavery, but without explicit reference to race $^{2}$. While by definition the terms "creole" and "creolization" can refer to the same sort of blendings as the terms mestizo and mestizaje, the former are seldom, if ever, employed in (or for) regions where the European/native mix predominates, and the contrary is also true: The term mestizo is seldom used for mixed-race people and their blended cultural forms in regions of Latin America where a European/African mix predominates.

Latin America's long history of biological and cultural mestizaje/creolization has yielded a wide range of musical hybrids, ranging from Colombian cumbia, Brazilian samba, Cuban mambo and Mexican mariachi to more contemporary blends such as salsa and reggaeton; these genres, have since been brought into the United States. Whether carried by Latin American immigrants or disseminated by sound recordings, these musics make up a significant (if underrecognized) part of the United States' sonic landscape. Within the United States, however, people of Latin American ancestry have discovered that mestizaje -whether their own racial and/or cultural hybridity or the aesthetic hybridity of their musics- has proved to be deeply problematic, profoundly influencing the ways US Latinos and their musical practices have been (mis)understood, and challenging their ability to articulate and perform their mestizaje.

Indeed, the seemingly obvious assertion that racial and cultural hybridity has shaped the contours of U.S. Latino musical practices, which would be uncontroversial in Latin America, has proved to be profoundly vexing in the context of the United States' particular racial formations and racial imaginaries. In the United States, where racial and cultural identities have historically been imagined in binary terms -that is, as black or white (both of which have been imagined in highly essentialist ways), the very idea of racial mixing and its consequent ambiguities have a long history of generating deeply rooted anxieties about boundaries, sexuality, and the body ${ }^{3}$.

The existence of a large and publicly acknowledged mixedrace category in Latin America -and its corresponding absence in the United States-underpins a profound cultural difference between the ways Spanish- and English-speaking Americans have identified themselves. Indeed, other than the derogatory term "half breed", there is no term in the United States analogous to mestizo or to its cognate, mestizaje, to describe the racial, cultural and musical mixing characterizing the post-conquest Americas. The term "mixed race" is close to but does not capture the historical specificities of the American hemisphere's racial profile; nor is it used as an adjective as it does in Spanish, for example, in the term cultura mestiza.

Given such fundamental conceptual differences in the ways of imagining racial identity, scholarly and popular discourse regarding cultural hybridity in (and about) the United States have been markedly different from those employed in (and about) Latin America. Scholars and other observers of Latin American music and culture routinely refer to the biological and cultural mixing that originally produced and shaped them, employing the concept of mestizaje to analyze cultural and musical developments, particularly in areas with predominantly mestizo populations; in areas whose populations are predominantly of African descent, the terms "creolization" or "syncretism" are used. Other images and metaphors have been used to describe or take into account the blending and mixing of people and/or cultural forms, including the term hybridity. (Although that term, like the term mestizaje, has been subject to increasing scrutiny and critique, which I will discuss further below). In the United States, in contrast, where anxieties about racial and cultural mixing have been -and remain- acute, bipolar racial imaginaries still generate much of the language used to describe popular music, such as the widely (if controversially) used term "black music" to describe the musics associated with African American communities -most of which are, to some degree, the product of cultural mixture 4 . Other styles of musics such as surf, heavy metal and punk music, are generally associated with whites (Euro-Americans) by fans and scholars alike, although they are not usually referred to explicitly as white music.

Musics associated with US Latinos, on the other hand, regardless of the nature and degree of their particular racial and cultural mixtures, have not generated analogous terms capturing the nature and nuances of their hybridity -and, as I have argued elsewhere, the terms "Latin music" and "Latino music", which are not equivalent, are highly imper- 
fect substitutes 5 . Indeed, the language of mestizaje drops out of the lexicon when musics of Latin American origins, already hybridized, arrive in the United States and are again transformed by musical exchanges within and across racial and ethnic boundaries. Rather than generating a term allowing for the transformation and blending of both parties involved in a cultural transaction, terms such as "borrowings", "influences", and "tinges" are used, which emphasize the degree of discreteness between the cultural domains of donor and receiver. One noticeable exception is the work of George Lipsitz, which has employed the postmodern concepts of "bifocality or reciprocity of perspectives, juxtaposition of multiple realities-intertextuality, inter-referentiality, and comparisons through families of resemblance" to explain the hybridity of Chicano musical practices (Lipsitz 1986, 157-177). But even in such work, the terms hybridity or mestizaje tend not to be used.

Instead, as Raquel Z. Rivera has noted, many U.S. scholars and other cultural observers still employ the prism of assimilation to interpret Latino musical practices, viewing Puerto Rican rappers, for example, as imitating African American culture, but reluctant to acknowledge Puerto Ricans as coparticipants in the development of hip hop culture in the 1970s and 80s. She also points out that it is seldom recognized that African American culture shares with Puerto Ricans a diasporic heritage, and that African American culture itself is also similarly hybrid (Rivera 2007, 351-362). In short, US Latino hybridity has been marked by being linguistically unnamed and thus out of place and profoundly "othered".

As I will discuss further below, the disavowal of racial and cultural mixture in the United States has been a powerful challenge to US Latinos' popular music practices because it has served to exclude them from musical domains perceived in binary terms, such as "black" (e.g., R \& B, hip-hop) and "white" (e.g., rock or pop). As Rivera (2007) has noted, even phenotypically black Latinos have been excluded from the "black" category precisely because they are members of a group -Latinos- recognized as mixed, and therefore considered essentially different. Mexican-origin mestizos in the United States have similarly found themselves relegated to an unstable position outside the "white" and "black" categories.

If the scholarship on racial, cultural, and musical hybridity in Latin America has undeniably provided useful theoreti- cal models to those analyzing U.S. Latino musical practices, it is important to keep in mind that the concept of mestizaje remains highly problematic because of its long history of being misused. Indeed, contemporary scholars of race relations in Latin America such as Helen Safa (1998), Peter Wade (2000) George Reid Andrews (2004), Miriam Jiménez Román (2007), Anani Dzidzienyo, and Suzanne Oboler (2005), have critiqued, if not roundly condemned, the concept of mestizaje because of its hidden implications and noxious consequences. They rightly charge, for example, that the implicit equation of mestizaje's hybridity with equality -that is, "we are all mixed so we are all equal"- has long been used in Latin America to avoid facing (and altering) the social, economic, and political structures responsible for perpetuating race-based "pigmentocracies", in which white-skinned individuals enjoy privileges of every sort; mixed-race people occupy an intermediate space depending on such variables as their phenotypical proximity to whiteness, education, wealth, and so forth; and people of more unambiguously African or native ancestry are subject to subordination and exploitation. The term hybridity has also been criticized for perpetuating discourses of racial difference, since it depends on essentialist notions of racial difference among its constituent parts.

The concept of mestizaje -and its critiques- are also problematic because they do not map neatly onto the domain of music. For example, Miriam Jiménez Román, who criticizes mestizaje's role in perpetuating racial inequalities in Latin America, observes that attempts to identify an individual's constituent parts account for the "assiduous attention paid to the phenotypical details that 'expose' African 'genes' and for the elaborate vocabulary that at once confers privilege and derides the subject under scrutiny. The conceptual difference between 'high yellow' and 'grifa' [both terms for a lighter shade of skin color] is truly insignificant and responds to the same historical privileging of certain physical characteristics over others" (Jiménez Roman 2007, 329). Jiménez Román's critique of efforts to identify the specific origins of an individual's phenotype is absolutely valid in the situation she describes, but it does not easily correspond to situations in which scholars seek to identify the constituent roots of Latino musical practices. Identifying the origins of African-derived drumming patterns in a particular style of Latino music, for example, does not have the same implications as trying to identify 
the origins of an individual's particular hue of skin -not to mention that the musicians performing such music may not be of African descent at all ${ }^{6}$.

Moreover, the constant aesthetic blending that has always characterized Latin/o American musical practices simply cannot be equated with the racist desires for blanqueamiento -genetic mixing whose goal has been to "improve the race" by "whitening" it. This is not to deny that correspondences exist between the problematic concepts of hybridity embedded within nationalist ideologies of mestizaje and the pernicious effects of racism in the domain of popular music. It is not coincidence that quintessentially hybrid musics originating in Latin America, such as Cuban son, Dominican merengue, and Colombian cumbia have become much celebrated symbols of national identity; it is precisely because they are perceived as expressing the literally and figuratively harmonious outcome of racial and cultural blending (despite the persistence of racially organized social hierarchies). In contrast, musics of unambiguously African and native origins have seldom had the same access to and success within the popular music marketplace as their more audibly hybrid counterparts.

Nonetheless, unlike social structures in which proximity to the ideal of phenotypical whiteness and Eurocentric culture shapes -and improves- an individual's or group's life chances, the most culturally and economically significant popular musics have emerged from the poorest, most dispossessed -and often the darkest- social sectors in Latin/o America: Cuban son, New York salsa, and Dominican bachata are but three examples. To be sure, before such grassroots styles could be accepted in bourgeois settings, they often underwent stylistic changes that distanced them from their lower-class (and more racially marked) versions, through a process of musical "whitening" in which musical aesthetics deemed too "black" were reduced or eliminated. But as the extraordinary cultural influence of musics originating in communities of color -such as the Afro-Cuban mambo and contemporary reggaeton- demonstrate, some of the most successful musical blendings have flourished not because they have been "whitened", but rather because of their strongly audible grounding in Afro-Latin aesthetics.

The fact that in the United States musical styles have been unambiguously associated with one racial group or another (as both producers and consumers), however, has left little space for multiracial, bicultural Latinos comfortable with and interested in aesthetic bridging rather than having to choose one identity or the other in order to succeed. Historically, Latinos who could "pass" as white could access the mainstream market, although only if they hid their ethnicity by changing their names, as did the 1940s pop singer Andy Russell and the 1950s rock ' $n$ ' roller Ritchie Valens, respectively born Andrés Rábago Pérez and Ricardo Valenzuela. In contrast, Afrodescendant Latinos who were phenotypically indistinguishable from African Americans had access to the "black" segment of the market, as did, for example, the Puerto Rican singer Herman Santiago in the doo-wop group Frankie Lymon and the Teenagers, which was identified as African American. More recently, Puerto Ricans Fat Joe and Big Pun began their careers in rap at a moment when it was perceived exclusively as a "black" music; only later, in the late 1990s, when rap began to be more widely acknowledged as a "ghettocentric" music that included Puerto Ricans, did these musicians begin to identify themselves as Puerto Ricans by employing Spanish lyrics and cover art iconography such as images of the Puerto Rican flag (Raquel Z. Rivera, personal communication).

In contrast, US Latinos of all racial backgrounds and national origins who would or could not relinquish their cultural hybridity and layered identities found themselves facing symbolic dangers and practical consequences. Latinos born and raised in the United States have long resisted the boundaries of the country's black and whiteonly categories, freely choosing musical sources and styles from among the wide array of possibilities offered by the nation's rich cultural demographics and reshaping them according to their own sensibilities and preferences. For example, Mexican American Latinos have been particularly active in the domain of rock music, which nonetheless has always been imagined as the product of a mixture of solely African American and Euro American sensibilities, and there are other examples I have cited elsewhere (Pacini Hernandez 2010). As a result, non-Latinos have perceived such efforts as second-rate imitations by cultural outsiders and interlopers rather than as natural expressions of bicultural Latino sensibilities. (Or for that matter, acknowledging that rock is an expression of the United States' own profound, if unacknowledged cultural hybridity.) 
The nature and degree of Latino musical hybridity has not been constant, however, varying according to local conditions and timing, in dialogue with larger national trends. Moreover, many Latinos have rejected such engagements as signs of cultural loss and betrayal. For example, during an era of intense cultural nationalism stimulated by the Civil Rights movements of the 1960s, the boogaloo, a blend of Spanish Caribbean and African American R \& B rhythms created by New York Puerto Ricans familiar with both traditions, was swept aside by the wave of salsa embraced by politically active musicians and fans, who perceived salsa's strong and audible roots in Spanish Caribbean traditions as representing a bulwark against U.S. cultural imperialism. At other times and in other places, however, US Latinos who have grown up familiar and comfortable with their hybrid cultural and musical genealogies have generally welcomed the opportunities and freedoms offered by mixing multiple musical traditions ${ }^{7}$.

It is important to note that within the United States, musical dialogues have taken place not only with well established non-Latino communities such as African Americans and Euro-Americans, but also with Latinos of different national and ethnic origins; for example, the Mexican-born Carlos Santana's career was based on his familiarity with both US blues and Afro Cuban rhythms. US Latinos also engage in musical dialogues and exchanges with more recently arrived Latin American immigrants; one example would be the incorporation of Mexican-style cumbias into Mexican-American musical styles, from Tejano and conjunto music to the eclectic rock of Los Angeles-based groups such as Ozomatli, intro- duced to the United States via the norteno music favored by working class Mexican immigrants. These intra-Latin/o American dialogues have been filtered and modulated by a characteristic common to both groups: a shared history of and openness to musical (and other sorts of) blending and recombination.

In summary, foregrounding the importance of hybridity for scholarship on US Latino communities and their musics is not intended to deny the problematic ways that mestizaje and other terms for racial and cultural hybridity have been used in the past, or to obscure the ways they can still be misused to mask persistent social inequalities. A case in point is the cynical celebration of Latinos' racial mixture by proponents of the concept of "colorblindness" when they argue for dismantling affirmative action because racial divisions in the United States supposedly no longer exist or matter as they did in the past (cf. Haney Lopez 2006). Those contesting such constructions, on the other hand, offer an equally disturbing scenario, in which Latinos' hybridity is believed to render them particularly prone to "buying in" to the United States' racial hierarchy, because Latinos (at least some of them) are able to "pass" as whites. Although there is certainly some truth to this latter analysis, the inability to imagine Latino hybridity as a progressive force in U.S. race relations means that all but the darkest-skinned Latinos are assumed to be "whites in waiting" or "honorary whites". I do, however, insist that US Latino voices be heard and understood on their own terms, which means fully appreciating their long and rich history of racial and cultural hybridity, and valuing their struggles to express and perform it.

\section{NOTES}

1 Portions of this essay are excerpted from my monograph Oye Como Va! Hybridity and Identity in Latino Popular Music (2010).

2 Martha Ellen Davis, for example, defines "creole" as "a cultural conglomerate born of Old World parentage and tempered by New World circumstance and creativity," while Kenneth Bilby defines "creolization" as the "meeting and blending of two or more older traditions on new soil, and a subsequent elaboration of form" (Davis 1994, 120; Bilby 1985, 182). Another term used to describe such cultural mixtures is "syncretism," in which European forms and meanings have been layered over African or Amerindian ones in order to avoid censure by officials seeking to ban supposedly primitive behaviors and practices.

3 C. F. Frances Aparicio, "Patriarchal Synechdotes: Of Women's Butts and Feminist Rebuttals", in Listening to Salsa: Gender, Latin Popular Music and Puerto
Recibido: 11 de noviembre de 2010 Aceptado: 15 de enero de 2011 
Rican Cultures (Wesleyan University Press, 1998), 142-153; and Myra Mendible's, From Bananas to Buttocks: The Latina Body in Popular Film and Culture (University of Texas Press, 2007.

4 Examples of the arguments made for and against the term "black music" can be found in Garofalo 1993, Hall 1992, Tagg 1989. Gilroy offers slightly differently inflected observations on the relationship between race, culture, and identity in his chapter "'Jewels Brought from Bondage': Black Music and the Politics of Authenticity" (1992, 72-110).

5 In brief, "Latin" music conflates Latin American and U.S. Latino musical productions. The term "Latino" is often misinterpreted as shorthand for Latin American and hence presents the same problem as "Latin". The term "U.S. Latino" does properly situate its subjects in the United States, although it also conflates profoundly different populations and styles, many of the latter not considered "Latin", such as Chicano rock. For a more extensive discussion of this issue, see Pacini Hernandez 2007.

6 It is noteworthy that scholarly interest in identifying constituent roots has not been uniform regarding musics of African and native derivation. The contributions of African-derived aesthetics to Latin/o American popular musics have been widely recognized and deconstructed, but the contributions of native derivation to multi-ethnic musics such as cumbia have seldom been sought as explicitly or as thoroughly.

7 My book Oye Como Va! focuses on the history of U.S. Latino engagements with mainstream and African American music and culture; numerous publications similarly address this issue, among them: Anthony Macias,
Mexican American Mojo: Popular Music, Dance, and Urban Culture in Los Angeles (Duke University Press, 2008); Manuel Peña's Música Tejana: The Cultural Economy of Artistic Transformation (Texas A \& M University Press, 1999, especially pp. 150217); Gustavo Perez Firmat's Life on the Hyphen: The Cuban American Way (University of Texas Press, 1994); Frances Negron-Muntaner's Boricua Pop: Puerto Ricans and the Latinization of American Culture (New York University Press, 2004).

\section{WORKS CITED}

Andrews, George Reid (2004): Afro-Latin America, New York: Oxford University Press.

Bilby, Kenneth M. (1985): "The Caribbean as a Musical Region", in Caribbean Contours, ed. Sidney W. Mintz and Sally Price, Baltimore: Johns Hopkins University Press, 181-218.

Davis, Martha Ellen (1994): "Music and Black Ethnicity in the Dominican Republic", in Music and Black Ethnicity: The Caribbean and South America, ed. Gerard H. Béhague, New Brunswick, NJ: Transaction Publishers, 119-155.

Dzidzienyo, Anani and Suzanne Oboler, eds. (2005): Neither Enemies nor Friends: Latinos, Blacks and Afro-Latins, New York: Palgrave.

Garofalo, Reebee (1993): "Black Popular Music: Crossing Over or Going Under?", in Rock and Popular Music: Politics, Policies and Institutions, ed. Tony Bennett; Simon Firth, Lawrence Grossberg, John Shepherd, Graeme Turner, New York: Routledge: 231-248.

Gilroy, Paul (1992): The Black Atlantic: Modernity and Double Consciousness, Cambridge: Harvard University Press.
Hall, Stuart (1992): "What Is This 'Black' in Black Popular Culture?", in Black Popular Culture, ed. Gina Dent, Seattle: South Bay Press, 255-263.

Haney Lopez, Ian F. (2006): "Colorblind to the Reality of Race in America", Chronicle of Higher Education, 53, no. 11, November 3.

Jiménez Román, Miriam (2007): "Looking at That Middle Ground: Racial Mixture as Panacea?", in A Companion to Latina/o Studies, ed. Juan Flores and Renato Rosaldo, Malden, MA: Blackwell Publishing, 325-336.

George Lipsitz (1986-1987): "Cruising around the Historical Bloc: Postmodernism and Popular Music in East Los Angeles", in Cultural Critique, 5 , Winter, 157-177.

Pacini Hernandez, Deborah (2007): "The Name Game: Locating Latinas/os, Latins, and Latin Americans in the US Popular Music Landscape", in A Companion to Latino Studies, ed. Juan Flores and Renato Rosaldo, Malden, MA: Blackwell Publishing, 49-59.

Pacini Hernandez, Deborah (2010): Oye Como Va! Hybridity and Identity in Latino Popular Music, Temple University Press.

Rivera, Raquel Z. (2007): "Between Blackness and Latinidad in the Hip Hop Zone", in A Companion to Latino Studies, ed. Juan Flores and Renato Rosaldo, Malden, MA: Blackwell Publishing, 351-362.

Safa, Helen (1998): "Race and National Identity in the Americas", in Latin American Perspectives, 25, no. 3, 320.

Tagg, Phillip (1989): "Open Letter about 'Black Music', 'Afro-American Music' and 'European Music'", Popular Music 8, no. 3, 285-298.

Wade, Peter (2000): Music, Race, and Nation: Música Tropical in Colombia, Chicago: University of Chicago Press. 